
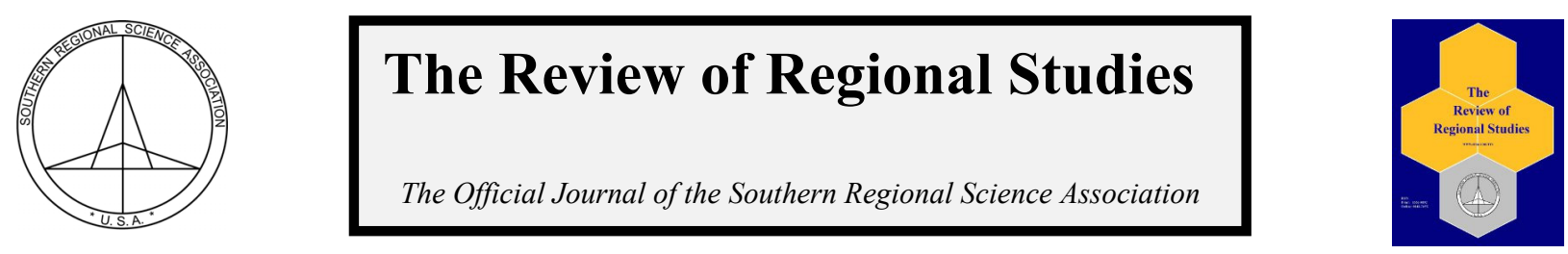

\title{
Outmigration and State and Local Appropriations for Public Higher Education $^{*}$
}

\author{
Robert R. Dunn
}

Department of Economics and Business, Washington \& Jefferson College, USA

\begin{abstract}
This paper focuses on the role of outmigration in determining public higher education funding from the 1993-1994 to the 2011-2012 academic years. The results of a fixed-effects estimation show that outmigration has a statistically significant and negative effect on the level of state funding when controlling for various state indicators, but the impact varies across state recessions and expansions. Findings on the role of state business cycles provide updated estimates of the relationship between migration and education funding but are generally in line with previous research.
\end{abstract}

Keywords: higher education funding, outmigration

JEL Codes: I22, R11, R23

\section{INTRODUCTION}

For the 2011-2012 school year, state and local appropriations accounted for more than 20 percent of public higher education total revenues and nearly 60 percent of non-operating revenues (NCES, Digest for Education Statistics). The primary economic justifications for higher education subsidies include development of an educated workforce and increased human capital stock within a state, while Oreopolous and Salvanes (2011) outline numerous external benefits of education. State and local appropriations to public higher education declined in real terms over the past ten years of the sample used in this paper (2002-2003 through 2011-2012) in 47 of the 48 continental states, with Wyoming being the exception. The average change in state and local funding across the 48 states represents a more than 27 percent decline. Over this same ten-year period, enrollment in public institutions increased in all 48 states with the increase averaging nearly 30 percent. While recent reductions have been particularly acute, this is part of a longer-term trend dating back to the 1980s. As state budgetary pressures increase, higher education is often the target of reduced government spending. Concomitantly, tuition and fees at public institutions of higher education have increased steadily as universities are forced to raise greater amounts of revenue to balance budgets. ${ }^{1}$ These trends make the examination of public higher education funding all the more timely. The possible determinants of state and local appropriation funding levels are numerous and complex, involving political, social, and economic aspects.

\footnotetext{
${ }^{*}$ The author would like to acknowledge valuable comments from Brian Cushing, Jon Winters, and two anonymous reviewers. Dunn is Associate Professor of Economics at Washington \& Jefferson College, Washington, PA. E-mail: rdunn@washjeff.edu ${ }^{1}$ For a more complete empirical discussion of this literature refer to Koshal and Koshal (1999, 2000), Lowry (2001), and Rizzo and Ehrenberg (2002). Fethke (2005) provides a theoretical foundation for this relationship which follows observed patterns in the U.S over the past several decades.
}

(C) Southern Regional Science Association 2015. ISSN 1553-0892, 0048-749X (online)

www.srsa.org/rrs 
Humphreys (2000) provides evidence that state business cycles play an important role in determining the level of state and local appropriations to higher education; this paper updates that analysis to some extent. Related to this, the education and regional science literatures present evidence that outmigration may be negatively capitalized into state spending on public higher education by legislators who are wary of missing out on the expected benefits of education due to the mobility of residents who are responding to the economic implications of increased outmigration. While it is not possible to isolate the migration behavior of college educated residents with this sample, gross outmigration is used as a proxy to examine the role of outmigration in the public higher education appropriations process following Strathman (1994) and Rizzo (2005). The ability to observe outmigration annually over 19 years yields more years of observation than previous researchers have been able to muster. It is possible to examine one of the mechanisms described above, but not tested in previous literature, between outmigration and public higher education spending; specifically the possibility that the loss of income and, therefore, revenue due to outmigration limits legislators' ability to spend on public higher education. In 2013, more than 46 percent of state and local tax revenue came from sales and gross receipts taxes while 42 percent was derived from personal income taxes for all states. ${ }^{2}$

The estimation results confirm that state-level economic conditions are of great importance, and they also show that gross state outmigration has a statistically and economically significant relationship with state and local public higher education appropriations per full-time equivalent (FTE) student. Specifically, a percentage point increase in outmigration leads to a \$339 decrease in appropriations per FTE student while controlling for other relevant political, social, and economic factors. This equates to a more than four percent drop based on the sample mean. Adjusted gross income (AGI) per out-migrant also has a statistically significant relationship with appropriations per FTE student which provides evidence that outmigration could reduce the amount of revenue available for public higher education funding, although the economic magnitude is relatively small. The findings here provide new, more detailed information about a relationship between outmigration and public higher education funding and confirm the importance of state economic conditions, as measured primarily by income per capita and state and local revenue per capita, in the decision making process.

\section{LITERATURE REVIEW}

As noted above, Humphreys (2000) identifies income levels and changes in income as crucial factors in explaining appropriations for public higher education. Using data from all 50 states for the years 1969 to 1994, the author shows that state appropriations are sensitive to business cycles. A similar relationship is found by Leslie and Ramey (1986) using regional-level data for enrollment and appropriations and the NBER coincident index as a national measure of the business cycle. ${ }^{3}$ Humphreys (2000) uses real appropriations at the state level and state real personal income per capita as a state specific measure of the business cycle. During a recession, income levels fall and states collects less tax revenues, which results in lower state appropriations to public higher education. On average, a one percent change in real per capita income resulted in a 1.39 percent change in real appropriations per student. Higher education

\footnotetext{
${ }^{2}$ Based on U.S. Census Bureau, Annual Survey of State and Local Government Finance.

${ }^{3}$ The NBER coincident index used by Leslie and Ramey (1986) is a weighted average of major economic indicators and includes data on production, employment, sales, and income. At the time is was prepared by NBER, the Federal Reserve Bank of Philadelphia now prepares a monthly Coincident Economic Activity Index for all 50 states that uses data on nonfarm payroll employment, average hours worked in manufacturing, unemployment rate, and real wage and salary disbursements.
}

(C) Southern Regional Science Association 2015. 
may also be treated as nonessential during a recession and may be faced with increased cuts in spending as state legislatures attempt to balance the budget. In a study on the University of Minnesota, Hoenack and Pierro (1990) report a positive but small income elasticity between tax revenues and appropriations suggesting that revenues and spending do move together. The results reported here are in line with these findings.

Turning to the role of migration, Weisbrod $(1962,1964)$ hypothesizes that within a welfare-maximizing community rational voters are cognizant of the possibility of outmigration of educated residents and the resulting loss of associated benefits. Specifically, communities that experience significant outmigration tend to underprovide primary and secondary public education expenditures in the absence of a system of intergovernmental transfers. In a later paper, Weisbrod (1965) tests this theory empirically using observations from the 48 contiguous states for the 1959-60 school year and concludes that states that had experienced net outmigration subsequently spent less per pupil on primary and secondary public schooling. Net inmigration, a proxy for any possible spill-in effects, did not have a statistically significant effect on primary and secondary public education spending and, therefore, did not offset the negative spill-out effects associated with outmigration of educated residents. Weisbrod rationalizes that any costs or benefits from inmigration can be regarded as fixed because they are independent of community public expenditure decisions. This result does not mean that school expenditures fall to a suboptimal level, it only shows that expenditures are lower, and therefore it may be incorrect to conclude that there is underinvestment (Isserman, 1976).

Greene (1977) responds that local governments, not states, are the proper unit of analysis given that levels of primary and secondary school expenditures are primarily a local decision. Furthermore, he notes that gross migration flows, rather than net, are more effective at providing an accurate understanding of the relationship between migration and school expenditures. Using a sample of 53 school districts in New York for the 1971-1972 school year, the author finds qualitative support for Weisbrod's conclusion. However, the empirical model is sensitive to changes in specification and, in equations with greater explanatory power, the effects of both inmigration and outmigration are quantitatively small. Neither Holland (1974) nor Hadley (1985) is able to find evidence of negative capitalization of outmigration in spending for primary and secondary education. Hadley (1985) argues that the strong correlation between migration and per capita income in the 1950s made accurate interpretation difficult. After updating Weisbrod's estimation for the 1976-1977 school year, Hadley finds no support for the welfare maximization hypothesis and determines that income levels are of great importance in explaining expenditures.

Focusing on public higher education inherently corrects for some difficulties mentioned above. The primary source of non-operating revenue for public institutions of higher education is state appropriations. Decisions on the size of appropriations take place at the state level, thus justifying the use of state-level migration data. Clotfelter (1976) examines the effect of outmigration of college graduates on state and local support of public higher education and expenditures per capita by public institutions in all 50 states in 1970. The total expenditure measure is further disaggregated into student-related expenditures and general expenditures not related to student services. If institutions negatively capitalize outmigration of college graduates into state expenditures for education, it does not follow that this should affect more general expenditures unrelated to educating students. Outmigration is measured as an approximation of 
the probability that an individual moves out of a state for some period of time in their life. ${ }^{4}$ Clotfelter reports a negative and statistically significant relationship between propensity for outmigration and higher education instructional expenditures per capita for 1970. The elasticity of migration is -0.442 with respect to expenditures on instruction. Outmigration is not significantly related to the measures of total expenditures, general expenditures, or state and local spending on public higher education. Clotfelter also concludes that increased enrollment and higher per capita income led to larger per capita higher education appropriations. Possible spill-in effects are not tested under the assumption that spending on higher education represents a fixed benefit and does not influence migration decisions.

Using a three-equation system to estimate factors affecting state and local appropriations, tuition revenue, and outmigration, Strathman (1994) tests for both spillover and spill-in effects of migration in the 48 contiguous U.S. states. He finds gross outmigration from 1985 to 1990 negatively affect state and local appropriations to public higher education for the 1989-1990 school year. A one percentage point increase in outmigration results in a $\$ 103$ reduction in appropriations per student. Inmigration does not have a statistically significant impact on appropriations. Rizzo (2006) reports similar results for 1977 to 2001 and measures outmigration as the share of the population five years prior that no longer resides in the state. The author shows that increased outmigration reduces the share of state education spending going toward higher education and also reduces the share of higher-education spending being appropriated directly to institutions. This paper updates these findings and expands the analysis by employing an annual panel data set featuring gross outmigration over 19 years.

Justman and Thisse $(1997,2000)$ develop theoretical models that identify the mechanisms through which interjurisdictional mobility leads to reduced investment in higher education when primary support is derived from subnational governments defined geographically, as is the case in the U.S. This type of structure also applies to the European Union, as skilled labor has become more mobile within the region over the past two decades. They argue that the incentives of state governments can be seriously compromised when mobility is relatively high, as it has traditionally been in the U.S.; they also note that current funding systems were developed at a time when migration was less common and more costly. Justman and Thisse argue that this focus on mobility at the subnational level can result in jurisdictions reducing expenditures on education to suboptimal levels.

Related empirical evidence on the link between state production of higher education and human capital stock in the state is presented by Bound et al. (2004). The authors find that the production of higher education has very little effect on the number of college educated workers in the state. Due to mobility, state investment in higher education has a limited ability to influence the stock of human capital within the state. Related to this, Groen (2004) finds only modest support for the hypothesis that attending a higher education institution within a state increases the probability of working in that state after graduation. He notes that the magnitude of the estimate is small and insufficient to justify broad-based merit-aid scholarship programs at the state level.

\footnotetext{
${ }^{4}$ The measure is constructed using eight age groups, 1 (25-29), 2 (30-34), 3 (35-39), 4 (40-44), 5 (45-49), 6 (50-54), 7 (55-59), 8 (60-64), from the 1970 Census. The proportion of individuals in each age group who migrated from a state between 1965 and 1970 is then combined to create a single measure of the propensity of an individual to move outside the state over the entire range of ages. The assumption is that the migration behavior of public college and university graduates is comparable to others in their age range.
}

(C) Southern Regional Science Association 2015. 
Merit-aid scholarship programs have been implemented in 25 states. They are designed to encourage college-bound students from moving out of state. Recent research that focuses specifically on the mobility impacts of these programs reports mixed findings. Malamud and Wozniak (2012) use data on Vietnam War draft avoidance and education decisions to show that obtaining additional education increases the likelihood that individuals with more years of higher education will live outside the state of their birth. Similarly, Sjoquist and Winters (2013) report that while Georgia HOPE scholarship program is effective at retaining students within the state for higher education, its recipients still have higher propensities to migrate out of the state after graduation. This is particularly true of high ability students in the study. Hawley and Rork (2013) report similar findings in that young, college-educated individuals are less likely to migrate out of states with scholarship programs but older, college-educated individuals are more likely to migrate out of these states. In contrast, Hickman (2009) finds that the Florida Bright Futures scholarship program increases the likelihood that eligible students remain in the state after graduation and Sjoquist and Winters (2014) report similar results when generalizing across all 25 such programs, although they note some state programs have no impact on outmigration.

Given the focus on migration behavior in this paper, specifically outmigration, it is important to note the longer-term pattern of reduced internal mobility since 1980 and the more recent decline since 2000. Molloy et al. (2011) provide a detailed overview of U.S. internal migration since 1980 and consider several hypotheses that could help explain this change in behavior. Similarly, Partridge et al. (2012) look at reduced interregional migration since 2000 and more formally consider the possibility that the U.S. has neared a spatial equilibrium, with amenities being more fully capitalized into land and housing prices, which would result in reduced movement. Using county-level data, the authors conclude that the reduction in mobility is the result of muted migration responses to local labor demand shocks. Individuals have been less likely to move after losing a job. These trends raise the possibility that migration behavior is having less of an impact on education funding decisions in recent years. But, like many prior researchers, Molloy et al. (2011) and Malamud and Wozniak (2012) note that migration rates among the higher-skilled and higher-educated are substantially higher relative to the general population.

\section{DATA AND METHODOLOGY}

Data on state and local appropriations and enrollments for all two- and four-year institutions of public higher education in the continental U.S. were collected for the 1993-1994 through 2011-2012 academic years. After adjusting for inflation, the data allowed for the creation of a measure of real state and local appropriations per FTE student expressed in thousands of 2010 dollars. These observations come from the Digest of Education Statistics published by the National Center for Education Statistics (NCES). ${ }^{5}$ State and local appropriations are classified as non-operating revenue sources by NCES and are an integral piece of public higher education funding at the state level. For the final year of this sample, 2011-2012, state and local appropriations accounted for 60.1 percent of non-operating revenue and 21.7 percent of total revenue at public higher education institutions in the U.S. The next largest single

\footnotetext{
${ }^{5}$ The exception to this is Colorado. In 2004, Colorado passed the College Opportunity Fund legislation that changed their higher education financing from a direct appropriations system to a voucher-based system for qualified residents (WICHE 2009). This substantially impacted the data reported to NCES and made it unusable for this analysis. Due to this, data for Colorado are sourced from the State Higher Education Finance Report published by the State Higher Education Executive Officers Association for all years of the sample (SHEEO, 2013).
}

(C) Southern Regional Science Association 2015. 
source of revenue, and the largest source of operating revenue, was tuition and fees which accounted for 20.6 percent of total revenue.

The independent variables of primary interest for this work are state outmigration and adjusted gross income (AGI) of out-migrants. Data on each come from the Internal Revenue Service (IRS), Statistics of Income, Migration Data, which are collected annually from 19911992 through 2009-2010. ${ }^{6}$ The outmigration observations are expressed as total outmigration from the state as a percentage of state population in the initial year. It should be noted that a more precise measure of outmigration of college-educated residents may be desirable to test the specific hypothesis that legislators are resistant to funding public higher education if it is demonstrated that graduates leave the state; however, that information is not available on an annual basis for the timeframe of this study. The U.S. Census Bureau's American Community Survey does provide data on mobility by educational attainment but this data series begins in 2005 and does not provide state-specific outmigration data. The IRS data are the best available and allow for closer examination of an association between total outmigration and public higher education funding compared with previous research. It is also true that more educated residents have traditionally moved at a higher rate than the population as a whole, as noted by Molloy et al. (2011) and Malamud and Wozniak (2012). For instance, 1.94 percent of the population moved between states during 2013 while 2.53 percent of those with a bachelor's degree moved between states. The AGI of out-migrants observations are also collected from the IRS data and are expressed as real AGI per out-migrant for each state. This allows for examination of the possibility that lost income from out-migrants reduces the ability of states to fund public higher education.

Independent variables relating to the economic conditions within a state start with real personal income per capita, sourced from the U.S. Bureau of Economic Analysis. This will provide a measure of the economic environment in each state and can also be seen as an indication of the ability and willingness of a state to fund public higher education. Additionally, annual real income growth is calculated to allow for identification of recessionary and expansionary years within each state. Additional information on state economic conditions is given by real total state and local revenue per capita, collected from the U.S. Census Bureau, and the ratio of the state unemployment rate to the national unemployment rate, constructed with data from the U.S. Bureau of Labor Statistics. Real total state and local revenue per capita is a measure of the ability of states to fund public higher education. While income and the associated taxes are an important source of revenue for many states, sales and gross receipts taxes are actually the largest source of revenue across all states as noted above and seven states have no state income tax. Relying on a measure of income alone may not sufficiently describe a state's ability to fund public higher education and relying on total revenues alone could be problematic as annual revenues are impacted by changes in policies and rates. The correlation between income and total revenue for the sample is 0.57 . Likewise, the level of unemployment is an important economic indicator. In this paper, a ratio of the state unemployment rate divided by the national unemployment rate indicates the state relative labor market environment. This should

\footnotetext{
${ }^{6}$ The timing of the IRS migration data is important to note. The 2009-2010 migration data are the most recent available and provide information on residence changes between calendar years 2009 and 2010 . The dates presented here are not related to tax years. It should also be noted that future IRS migration data will include additional information that allows for disaggregation by age and income ranges, however this type of information was not available for the current sample.
}

(C) Southern Regional Science Association 2015. 
also help to control for the possibility that any estimated impacts of outmigration are actually capturing the impacts of a deteriorating labor market.

Other independent variables include total FTE enrollment in public higher education, percent of enrollment in private institutions, a measure of educational attainment, median age, and political party in power. Total FTE enrollment in public higher education is meant to control for the impact of economies of scale that could lead to reduced funding on a per student basis. Controlling for the share of total higher education enrollment that is in private institutions provides a measure of the demand or preference for public higher education in a state. Both enrollment measures come from data in the Digest of Education Statistics, NCES. Educational attainment is measured as the share of the state population with at least a bachelor's degree. A state with a higher share of college graduates should more likely place greater value on access to higher education and be more willing to fund it. Median age provides a measure of the age distribution in a state. States with a higher median age may be less willing and/or more able to fund public higher education and may place more importance on other spending areas. The educational attainment and median age observations come from the U.S. Census Bureau. Finally, to control for political factors, a dummy variable is created that is equal to one if both the state legislature and the governor's office are controlled by Republicans and equal to zero otherwise. ${ }^{7}$ This variable was constructed using data from the National Conference of State Legislatures and the National Governors Association.

Table 1: Descriptive Statistics

\begin{tabular}{lrrrr}
\hline \hline Variable $(n=911)$ & Mean & Std. Dev. & \multicolumn{1}{c}{ Min. } & \multicolumn{1}{c}{ Max. } \\
\hline Real appropriations per FTE & 7,963 & 2,011 & 2,209 & 15,919 \\
Growth rate of real appropriations & -1.31 & 7.79 & -41.81 & 56.53 \\
Outmigration & 2.97 & 0.80 & 1.31 & 5.85 \\
Real income per capita & 36,460 & 6,143 & 23,286 & 58,566 \\
Growth rate of real income per capita & 1.43 & 2.23 & -11.16 & 9.65 \\
Real total revenue per capita & 8,475 & 1,803 & 5,279 & 18,652 \\
Growth rate of total revenue & 3.03 & 13.07 & -40.32 & 106.61 \\
Adjusted gross income per out-migrant & 30,899 & 8,535 & 16,005 & 82,163 \\
Enrollment & 185,680 & 205,588 & 15,426 & $1,468,908$ \\
Growth rate of enrollment & 2.06 & 3.02 & -9.81 & 18.83 \\
Unemployment ratio & 0.99 & 0.21 & 0.39 & 1.68 \\
Median age & 35.9 & 2.2 & 26.7 & 42.4 \\
Educational attainment & 24.3 & 4.8 & 13.1 & 38.7 \\
Percent private enrollment & 22.8 & 12.4 & 1.2 & 57.7 \\
Republican control & 0.23 & 0.42 & 0 & 1 \\
\hline \hline
\end{tabular}

\footnotetext{
${ }^{7}$ The estimations were also completed with separate dummy variables for the state legislature and the governor's office and the results were very similar to those reported below. The combined dummy variable measure exhibited the most explanatory power.
}

(C) Southern Regional Science Association 2015. 
All independent variables are lagged one year to account for the timing of the legislative decision making process. It is unlikely that legislators will have immediate access to information on economic conditions in their state and, even if they do, the timing of the budgeting cycle is likely to mean that they cannot act on this information right away. The lag of the independent variables has the additional benefit of limiting concerns of bias that could be introduced by the existence of any unobservable factors. There are a total of 911 state-level observations as Alaska and Hawaii are not included in the sample because the decision to migrate out of these states is not comparable to the outmigration decision among the continental states. The observation for Louisiana in 2006 is dropped from the sample as outmigration from the state was substantially impacted by the effects of Hurricane Katrina, although appropriations and income were impacted to a lesser degree in that year. Descriptive statistics for all variables can be found in Table 1.

A fixed-effects panel data model is estimated that allows me to control for any timeinvariant state-specific factors that may impact appropriations. In addition, a year dummy variable $(\alpha)$ is created to control for any factors that may have impacted all states in a given year. The reduced form model to be estimated is motivated by the work of Humphreys (2000) that demonstrates the need to control for time and non-varying state specific effects when examining state and local appropriations. Humphreys (2000) focuses specifically on the relationship between income per capita and state and local appropriations while the model presented here considers several additional explanatory variables that may impact the level of appropriations in a state, with a primary interest in the role of outmigration. This expanded model takes the following form:

$$
\begin{aligned}
& \text { (1) } \text { app }_{i, t}=\alpha_{t}+\gamma_{i}+\beta_{1} \text { outmig }_{i, t}+\beta_{2} \text { outagi }_{i, t}+\beta_{3} \text { inc }_{i, t}+\beta_{4} \boldsymbol{r e v}_{i, t}+ \\
& \beta_{5} \text { enroll }_{i, t}+\beta_{6} \text { uemp }_{i, t}+\beta_{7} \text { age }_{i, t}+\beta_{8} \text { edu }_{i, t}+\beta_{9} \text { priv }_{i, t}+\beta_{10} \boldsymbol{r e p}_{i, t}+\boldsymbol{u}_{i, t}
\end{aligned}
$$

where app is real state and local appropriations to public higher education per FTE student, outmig is total state outmigration as a percent of state population, outagi is real adjusted gross income per out-migrant, inc is real personal per capita income, rev is real total state and local revenue per capita, enroll is total FTE enrollment in public higher education, uemp is the ratio of the state unemployment rate to the national unemployment rate, age is median age, $\boldsymbol{e d u}$ is percent of the population with at least a bachelor's degree, priv is the percent of students enrolled in private higher education institutions, and rep is a dummy variable equal to one if the state legislature and governor's office are controlled by Republicans. The subscript $i$ indicates state and $\boldsymbol{t}$ indicates year with $\boldsymbol{\gamma}_{\boldsymbol{i}}$ and $\boldsymbol{\alpha}_{\boldsymbol{t}}$ representing state and year fixed effects, respectively.

In addition to examining the level of state and local appropriations per FTE student, it is also useful to consider the rate of change of state and local appropriations. Although total enrollments are controlled for in the initial estimation, this specification allows for the removal of any impacts of enrollment changes and can also control for any unobservable factors between states that could be relevant to public higher education funding. While Humphreys (2000) considers the relationship between income growth and appropriations growth, this analysis updates and expands on that by introducing measures of the growth in total revenue and enrollment while retaining all other control variables from Equation (1). This results in the following empirical model to be estimated:

$$
\begin{aligned}
& \text { (2) } \text { appg }_{i, t}=\alpha_{t}+\gamma_{i}+\beta_{1} \text { outmig }_{i, t}+\beta_{2} \text { outagi }_{i, t}+\beta_{3} \text { incg }_{i, t}+\beta_{4} \text { revg }_{i, t}+ \\
& \beta_{5} \text { enrollg }_{i, t}+\beta_{6} \text { uemp }_{i, t}+\beta_{7} \text { age }_{i, t}+\beta_{8} \text { edu }_{i, t}+\beta_{9} \text { priv }_{i, t}+\beta_{10} \text { rep }_{i, t}+\boldsymbol{u}_{i, t}
\end{aligned}
$$


where appg is the annual growth rate of real state and local appropriations to public higher education, incg is the annual growth rate of real personal per capita income, revg is the annual growth rate of real total state and local revenue per capita, and enrollg is the annual growth rate of total FTE enrollment in public higher education.

\section{ESTIMATION RESULTS}

The estimation results concerning the level of state and local appropriations to public higher education per FTE student are presented below in Table 2. In keeping with previous work in the area, specifically Strathman (1994) and more recently Rizzo (2006), the rate of outmigration has a negative relationship with state and local appropriations per FTE student that is significant at the one percent level as shown in the Model 1 results. A one percentage point increase in outmigration is associated with a $\$ 339$ decrease in appropriations per FTE student while the implied elasticity is relatively small at -0.13 . Although the results are not reported here, different lag structures for the outmigration variable were considered to examine the robustness of the estimates. The relationship between appropriations and outmigration with no lag proves to be statistically insignificant, providing evidence that the relationship is not spurious. The coefficient on outmigration lagged two years is estimated to be $\$ 323$ and is statistically significant at the five percent level while a lag of three years is statistically insignificant. These results taken as a whole suggest that prior outmigration trends impact appropriation levels but the effects are relatively short lived as would be expected if decision makers are responding to more recent developments.

The average AGI of out-migrants is also statistically significant at the one percent level, although the magnitude is small with a $\$ 1,000$ increase in AGI per out-migrant associated with a nearly $\$ 20$ reduction in appropriations per FTE student. The implied elasticity is close to zero at -0.08 . The results indicate that increased outmigration in general is associated with a reduction in public higher education funding and, while average AGI of out-migrants is statistically significant, it seems that its economic significance is somewhat limited.

The estimated relationship between state and local appropriations and income is also in keeping with previous findings, as real personal per capita income increases by $\$ 1,000$, appropriations per FTE student increase by approximately $\$ 252$. Based on the estimates and the variable means, the elasticity between the two variables is 1.15 . Humphreys (2000) reported a coefficient estimate of $\$ 430$ and an elasticity of 1.39 using an earlier sample from 1969 to 1994. The fact that the coefficient estimate and elasticity reported here are smaller than the estimates in the previous work is not surprising as overall funding levels have decreased over time and there is likely less room for further discretionary reductions in appropriations. State and local total revenue per capita exhibits a similar relationship, as a $\$ 1,000$ increase in total revenue per capita is associated with a nearly $\$ 116$ increase in appropriations per FTE student, but the elasticity is considerably less at 0.12 . Of these four variables, the elasticity estimates not surprisingly suggest that income is the most important factor for determining the level of public higher education funding. This is likely due to the importance of income as a source of revenue and to the fact that increases or decreases in income are strong signals of economic conditions within a state. As mentioned above, total state and local revenue per capita may have a less direct relationship with public higher education funding due to changes in tax rates and policies and the variety of sources from which revenue is pulled. This could lead to revenue being a less clear signal of the economic conditions in a state.

(C) Southern Regional Science Association 2015. 
Table 2: FE Estimation Results (Dep. Var. = Appropriations per FTE)

\begin{tabular}{|c|c|c|c|c|}
\hline Variable $(n=911)$ & Model 1 & Model 2 & Model 3 & Model 4 \\
\hline Outmigration(t-1) & $\begin{array}{c}-338.9^{* * * *} \\
(2.59)\end{array}$ & & $\begin{array}{c}-337.5^{* * * *} \\
(2.59)\end{array}$ & $\begin{array}{c}-338.3^{* * * *} \\
(2.59)\end{array}$ \\
\hline 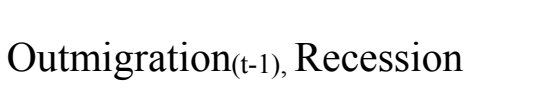 & & $\begin{array}{c}-294.2 * * \\
(2.23)\end{array}$ & & \\
\hline Outmigration(t-1) $_{(\text {Expansion }}$ & & $\begin{array}{c}-346.6 * * * \\
(2.66)\end{array}$ & & \\
\hline Income per capita, thousands(t-1) & $\begin{array}{c}252.3 * * * \\
(11.98)\end{array}$ & $\begin{array}{c}259.1 * * * \\
(12.22)\end{array}$ & & $\begin{array}{c}257.8 * * * \\
(12.17)\end{array}$ \\
\hline $\begin{array}{l}\text { Income per capita(t-1), } \\
\text { Recession }\end{array}$ & & & $\begin{array}{c}259.8^{* * *} \\
(12.17)\end{array}$ & \\
\hline $\begin{array}{l}\text { Income per capita(t-1), } \\
\text { Expansion }\end{array}$ & & & $\begin{array}{c}256.1^{* * *} \\
(12.14)\end{array}$ & \\
\hline $\begin{array}{l}\text { Revenue per capita, } \\
\text { thousands(t-1) }\end{array}$ & $\begin{array}{c}115.8^{* * *} \\
(2.96)\end{array}$ & $\begin{array}{c}113.0^{* * *} \\
(2.90)\end{array}$ & $\begin{array}{c}116.6^{* * *} \\
(2.99)\end{array}$ & \\
\hline $\begin{array}{l}\text { Revenue per capita (t-1), } \\
\text { Recession }\end{array}$ & & & & $\begin{array}{c}128.6^{* * *} \\
(3.26)\end{array}$ \\
\hline $\begin{array}{l}\text { Revenue per capita(t-1), } \\
\text { Expansion }\end{array}$ & & & & $\begin{array}{c}112.4 * * * \\
(2.88)\end{array}$ \\
\hline $\begin{array}{l}\text { AGI per out-migrant, } \\
\text { thousands(t-1) }\end{array}$ & $\begin{array}{c}-19.5^{* * * *} \\
(2.61)\end{array}$ & $\begin{array}{c}-19.3 * * * \\
(2.59)\end{array}$ & $\begin{array}{c}-19.2 * * \\
(2.56)\end{array}$ & $\begin{array}{c}-19.4 * * * \\
(2.60)\end{array}$ \\
\hline FTE Enrollment, thousands(t-1) & $\begin{array}{c}-2.27 * * * \\
(3.19)\end{array}$ & $\begin{array}{l}-2.19 * * * \\
(3.08)\end{array}$ & $\begin{array}{c}-2.27 * * * \\
(3.19)\end{array}$ & $\begin{array}{c}-2.23 * * * \\
(3.14)\end{array}$ \\
\hline Unemployment ratio(t-1) & $\begin{array}{c}-654.2 * * * \\
(3.32)\end{array}$ & $\begin{array}{c}-703.7 * * * \\
(3.57)\end{array}$ & $\begin{array}{c}-700.6^{* * *} \\
(3.54)\end{array}$ & $\begin{array}{c}-696.1 * * * \\
(3.52)\end{array}$ \\
\hline Median age $(\mathrm{t}-1)$ & $\begin{array}{c}-115.7 * * \\
(2.30)\end{array}$ & $\begin{array}{c}-104.0^{* *} \\
(2.07)\end{array}$ & $\begin{array}{c}-111.3 * * \\
(2.22)\end{array}$ & $\begin{array}{c}-110.7 * * \\
(2.20)\end{array}$ \\
\hline Educational attainment $(\mathrm{t}-1)$ & $\begin{array}{c}-372.0 * * * \\
(6.30)\end{array}$ & $\begin{array}{c}-377.2 * * * \\
(6.40)\end{array}$ & $\begin{array}{c}-379.4 * * * \\
(6.42)\end{array}$ & $\begin{array}{c}-378.6^{* * * *} \\
(6.41)\end{array}$ \\
\hline Percent private enrollment $(t-1)$ & $\begin{array}{l}-5.15 \\
(0.81)\end{array}$ & $\begin{array}{l}-5.15 \\
(0.82)\end{array}$ & $\begin{array}{l}-4.98 \\
(0.79)\end{array}$ & $\begin{array}{l}-5.00 \\
(0.79)\end{array}$ \\
\hline Republican control $(\mathrm{t}-1)$ & $\begin{array}{c}-303.1 * * * \\
(4.07)\end{array}$ & $\begin{array}{c}-305.8 * * * \\
(4.11)\end{array}$ & $\begin{array}{c}-302.5^{* * *} \\
(4.07)\end{array}$ & $\begin{array}{c}-303.6^{* * *} \\
(4.08)\end{array}$ \\
\hline $\begin{array}{l}R^{2} \\
F \text {-stat }\end{array}$ & $\begin{array}{c}0.71 \\
74.51\end{array}$ & $\begin{array}{c}0.72 \\
72.54\end{array}$ & $\begin{array}{c}0.72 \\
72.34\end{array}$ & $\begin{array}{c}0.72 \\
72.37\end{array}$ \\
\hline
\end{tabular}

Total FTE enrollment is statistically significant at the one percent level and indicates that economies of scale are present in funding as states with larger enrollments tend to have lower appropriations per FTE student. As expected, the unemployment ratio is negative and statistically significant at the one percent level. As a state experiences an unemployment rate above the

(C) Southern Regional Science Association 2015. 
national unemployment rate, funding for public higher education per FTE student decreases, although the corresponding elasticity is relatively low at -0.08 . This is further evidence of the relationship between state economic conditions and public higher education funding. The results also indicate that states with older populations are less willing and/or able to fund public higher education and, surprisingly, states with higher levels of educational attainment, measured as the percent of the population with at least a bachelor's degree, are also less willing to fund public higher education. Finally, states in which the Republican Party controls both the legislature and the governor's office tend to have lower state and local appropriations per FTE student over the sample period. The descriptive statistics show that this situation of Republican control occurred 23 percent of the time across the 48 states and 19 years comprising the sample.

Models 2, 3, and 4 add an additional layer of information by examining the possibility that outmigration, income, or state and local revenues impact appropriations per FTE student differently during state recessions and expansions. To identify such effects, two dummy variables were created that identified recessionary years within a state as those that had negative income growth and identified expansionary years within a state as those that had positive income growth. ${ }^{8}$ Of the 911 observations in the sample 203 were identified as recessionary (22.3 percent) while the remaining 708 were identified as expansionary ( 77.7 percent $)$. This is a higher proportion of recessionary years than the sample used by Humphreys (2000) due to the financial crisis of the late 2000s and ensuing national recession.

The estimation results in Model 2 indicate that outmigration has a more negative impact on public higher education funding during expansions compared with recessions. An F-test of the equality of these two coefficients rejects the null hypothesis at the five percent level of significance. The reduction in appropriations associated with outmigration is 16.4 percent larger during expansionary periods. The impact of changes in income per capita on appropriations per FTE student proves to be more consistent across expansions and recessions as shown in Model 3, although an F-test indicates that the coefficients are statistically different at the five percent level with impacts being larger during recessions. However, the difference between the estimated coefficients is only 1.4 percent. Finally, Model 4 shows that the estimates for state and local revenue per capita are similar to those for income with larger associated impacts during recessions compared with expansions. This is confirmed with an $F$-test that rejects the null hypothesis of equality of the coefficients at the five percent level of significance. The sign and statistical significance of the other estimated coefficients are consistent across all specifications. Taking the results for income and revenue together leads to the conclusion that state and local appropriations per FTE student tend to decrease more during recessions than they increase during expansions. These estimates do not necessarily imply reduced funding overall, as expansionary periods are more much more frequent than recessionary periods. Outmigration shows the opposite pattern of having a greater estimated impact during expansions. This may be due to the fact that other economic indicators, namely income and total revenue, are of more importance to decision makers during recessionary periods, while outmigration during an expansion may lead to decision makers being less willing to commit funds to public higher education.

\footnotetext{
${ }^{8}$ This extension follows Humphreys (2000) and is not specifically in line with the NBER dating process but is similar. There were no years with exactly 0 income change.
}

(C) Southern Regional Science Association 2015. 
The results reported in Table 3 examine the growth rate of real state and local appropriations with the variables related to income, revenue, and enrollment also being measured as growth rates. The results for Model 1 indicate that the growth rate of real personal per capita income is estimated to have a positive relationship with the growth rate of state and local appropriations at the one percent level of significance. No other variables in this estimation are statistically significant, which shows that while they may be determinants of the level of funding they are not relevant when considering the rate of change in funding. Examining the growth rate of income per capita across expansions and recessions results in a significantly different outcome than that reported above. The growth rate of income per capita has a positive and statistically significant relationship with the growth rate of appropriations during recessions but not during expansions. This is similar to the findings of Humphreys (2000), although he reports a statistically significant relationship during both expansions and recessions with the coefficient estimate during expansions $(0.188)$ being considerably smaller than the estimate during

Table 3: FE Estimation Results (Dep. Var. = Growth Rate of Appropriations)

\begin{tabular}{|c|c|c|}
\hline Variable $(n=911)$ & Model 1 & Model 2 \\
\hline Outmigration $_{(\mathrm{t}-1)}$ & $\begin{array}{l}-0.636 \\
(0.49)\end{array}$ & $\begin{array}{l}-0.661 \\
(0.51)\end{array}$ \\
\hline AGI per out-migrant, thousands(t-1) & $\begin{array}{l}-0.036 \\
(0.49)\end{array}$ & $\begin{array}{l}-0.040 \\
(0.55)\end{array}$ \\
\hline Growth rate of per capita income $(\mathrm{t}-1)$ & $\begin{array}{c}0.472 * * * \\
(3.41)\end{array}$ & \\
\hline Growth rate of per capita revenue(t-1) & $\begin{array}{l}-0.019 \\
(0.64)\end{array}$ & $\begin{array}{l}-0.018 \\
(0.63)\end{array}$ \\
\hline Growth rate of FTE enrollment $(\mathrm{t}-1)$ & $\begin{array}{l}-0.106 \\
(1.11)\end{array}$ & $\begin{array}{l}-0.106 \\
(1.11)\end{array}$ \\
\hline Unemployment ratio(t-1) & $\begin{array}{l}-1.456 \\
(0.84)\end{array}$ & $\begin{array}{l}-1.580 \\
(0.91)\end{array}$ \\
\hline Median age $(\mathrm{t}-1)$ & $\begin{array}{l}-0.367 \\
(0.75)\end{array}$ & $\begin{array}{l}-0.518 \\
(1.05)\end{array}$ \\
\hline Educational attainment $(\mathrm{t}-1)$ & $\begin{array}{l}-0.038 \\
(0.07)\end{array}$ & $\begin{array}{l}-0.117 \\
(0.22)\end{array}$ \\
\hline Percent private enrollment $(\mathrm{t}-1)$ & $\begin{array}{l}-0.011 \\
(0.17)\end{array}$ & $\begin{array}{l}-0.010 \\
(0.17)\end{array}$ \\
\hline Republican control $_{(\mathrm{t}-1)}$ & $\begin{array}{l}-1.007 \\
(1.38)\end{array}$ & $\begin{array}{c}-0.979 \\
(1.34)\end{array}$ \\
\hline Growth rate of income $(\mathrm{t}-1)$, Recession & & $\begin{array}{c}1.039 * * * \\
(3.19)\end{array}$ \\
\hline Growth rate of income(t-1), Expansion & & $\begin{array}{c}0.261 \\
(1.48)\end{array}$ \\
\hline$R^{2}$ & 0.43 & 0.43 \\
\hline$F$-stat & 22.52 & 22.52 \\
\hline
\end{tabular}

Note. $t$-statistics reported in parentheses. Levels of significance: *** $1 \% ; * * 5 \% ; * 10 \%$. 
recessions (0.870). These results, along with those reported above, provide evidence that the cuts to funding associated with a drop in income per capita during recessions are larger than the increases in funding associated with a rise in income per capita during expansions and it is likely that changes in enrollment may mask this to some extent when examining funding per FTE student. In addition, this discrepancy between public higher education funding during expansions and recessions seems to have widened over the past two decades.

\section{CONCLUSION}

This paper focuses on the relationship between state outmigration rates and state and local appropriations for public higher education while also considering the impacts of other political, social, and economic variables. The sample utilized spans the 1993-1994 to 2011-2012 academic years and relies on annual migration data from the IRS to construct a panel data set. This differs from previous research that has been restricted to considerably fewer observations of outmigration. The results of the fixed-effects estimation show that increased rates of outmigration are associated with decreased levels of state and local appropriations per FTE student. Specifically, a one percentage point increase in outmigration leads to a $\$ 339$ reduction in funding per FTE student, a more than four percent decrease based on the sample mean. This result supports Justman and Thisse $(1997,2000)$ who suggest education funding at a subnational level can lead to underinvestment as jurisdictions become increasingly worried about mobility of residents. While the available data do not allow for disaggregation by age or education, future IRS data will allow for disaggregation by age and utilization of these more detailed observations would represent a valuable addition to the literature.

One specific mechanism of this relationship between outmigration and appropriations per FTE student is able to be tested here, the possibility that a loss of income from out-migrants limits the ability of a state to fund public higher education. The measure of AGI per out-migrant does prove to be statistically significant but the economic magnitude is limited, suggesting that a simple loss of income and associated revenue from out-migrants is likely not a major factor in the determination of public higher education funding levels.

In addition to the findings related to outmigration, the results show that income per capita and total state and local revenue per capita each have a positive relationship with state and local appropriations per FTE student as expected. The elasticity associated with income is estimated to be 1.15 while the elasticity associated with total state and local revenue is estimated to be 0.12 . Following these initial findings, a dummy variable is created to identify state-specific expansions and recessions with the intent of examining how impacts may differ across the business cycle. The ensuing estimates indicate that changes in the outmigration rate have relatively larger impacts during expansions while changes in income per capita and total revenue per capita have relatively larger impacts during recessions. Examination of the growth rate of state and local appropriations and the growth rate of income per capita, which allows for removal of any enrollment effects, supports the finding that appropriations are reduced more during recessions than they are increased during expansions. In summary, the findings presented here highlight a number of factors that are important for the determination of state and local appropriations per FTE student over the sample period and provide more detailed evidence of the relationship between public higher education funding and outmigration.

(C) Southern Regional Science Association 2015. 


\section{REFERENCES}

Bound, John, Jeffrey Groen, Gabor Kezdi, and Sarah Turner. (2004) "Trade in University Training: Cross-state Variation in the Production and Stock of College-educated Labor," Journal of Econometrics, 121, 143-173.

Clotfelter, Charles T. (1976) "Public Spending for Higher Education: An Empirical Test of Two Hypotheses," Public Finance, 32, 177-194.

Fethke, Gary. (2005) "Strategic Determination of Higher Education Subsidies and Tuitions," Economics of Education Review, 24, 601-609.

Greene, Kenneth V. (1977) "Spillovers, Migration, and Public School Expenditures: The Repetition of an Experiment," Public Choice, 29, 85-93.

Groen, Jeffrey A. (2004) "The Effect of College Location on Migration of College-Educated Labor," Journal of Econometrics, 121, 125-142.

Hadley, Garland R. (1985) "Interstate Migration, Income and Public School Expenditures: An Update of an Experiment," Public Choice, 46, 207-214.

Hawley, Zackary B. and Jonathan C. Rork. (2013) "The Case of State Funded Higher Education Scholarship Plans and Interstate Brain Drain," Regional Science and Urban Economics, 43, 242-249.

Hickman, Daniel C. (2009) "The Effects of Higher Education Policy on the Location Decision of Individuals: Evidence from Florida's Bright Futures Scholarship Program," Regional Science and Urban Economics, 39, 553-562.

Hoenack, Stephen A. and Daniel J. Pierro. (1990) "An Econometric Model of a Public University's Income and Enrollments," Journal of Economic Behavior and Organization, $14,403-423$.

Holland, David W. (1974) "The Impact of Benefit Spillovers Upon Economic Efficiency in Public School Finance," American Journal of Agricultural Economics, 56, 300-305.

Humphreys, Brad R. (2000) "Do Business Cycles Affect State Appropriations to Higher Education?” Southern Economic Journal, 67, 398-413.

Isserman, Andrew M. (1976) "Interjurisdictional Spillovers, Political Fragmentation and the Level of Local Public Services: A Re-examination,” Urban Studies, 13, 1-12.

Justman, Moshe and Jacques François Thisse. (1997) "Implications of the Mobility of Skilled Labor for Local Public Funding of Higher Education," Economics Letters, 55, 409-412. . (2000) "Local Public Funding of Higher Education When Skilled Labor is Imperfectly Mobile," International Tax and Public Finance, 7, 247-258.

Koshal, Rajindar K. and Manjulika Koshal. (1999) "Economies of Scale and Scope in Higher Education: A Case of Comprehensive Universities," Economics of Education Review, 18, 269-277.

. (2000) "State Appropriations and Higher Education Tuition: What is the Relationship?," Education Economics, 8, 81-89.

(C) Southern Regional Science Association 2015. 
Leslie, Larry L. and Garey Ramey. (1986) "State Appropriations and Enrollments, Does Enrollment Growth Still Pay?," Journal of Higher Education, 57, 1-19.

Lowry, Robert C. (2001) "The Effects of State Political Interests and Campus Outputs on Public University Revenues," Economics of Education Review, 20, 105-119.

Malamud, Ofer and Abigail Wozniak. (2012) "The Impact of College on Migration: Evidence from the Vietnam Generation," Journal of Human Resources, 47, 913-950.

Molloy, Raven, Christopher L. Smith, and Abigail Wozniak. (2011) "Internal Migration in the United States,” Journal of Economic Perspectives, 25, 173-196.

Oreopoulos, Philip and Kjell G. Salvanes. (2011) "Priceless: The Nonpecuniary Benefits of Schooling," Journal of Economic Perspectives, 25, 159-184.

Partridge, Mark D., Dan S. Rickman, M. Rose Olfert, and Kamar Ali. (2012) "Dwindling U.S. Internal Migration: Evidence of Spatial Equilibrium or Structural Shifts in Local Labor Markets?," Regional Science and Urban Economics, 42, 375-388.

Rizzo, Michael J. (2006) "State Preferences for Higher Education Spending: A Panel Data Analysis, 1977-2001," in Ronald G. Ehrenberg (ed.), What's Happening to Public Higher Education? The Johns Hopkins University Press: Baltimore, pp. 3-36.

Rizzo, Michael J. and Ronald G. Ehrenberg. (2002) "Resident and Nonresident Tuition and Enrollment at Flagship State Universities," National Bureau of Economic Research Working Paper 9516: Cambridge, Massachusetts.

Sjoquist, David L. and John V. Winters. (2013) "The Effects of HOPE on Post-College Retention in the Georgia Workforce," Regional Science and Urban Economics, 43, 479-490.

. (2014) "Merit Aid and Post-College Retention in the State," Journal of Urban Economics, 80, 39-50.

State Higher Education Executive Officers Association. (2013) State Higher Education Finance. Available at: http://www.sheeo.org/projects/shef-\%E2\%80\%94-state-higher-educationfinance.

Strathman, James G. (1994) "Migration, Benefit Spillovers and State Support of Higher Education," Urban Studies, 31, 913-920.

Weisbrod, Burton A. (1962) "Education and Investment in Human Capital," Journal of Political Economy, 70, 106-123.

- (1964) External Benefits of Public Education: An Economic Analysis. Princeton University Press: Princeton, New Jersey.

. (1965) "Geographic Spillover Effects and the Allocation of Resources to Education," in J. Margolis (ed.), The Public Economy of Urban Communities. Resources for the Future: Washington, D.C.

Western Interstate Commission for Higher Education. (2009) An Evaluation of Colorado's College Opportunity Fund and Related Policies. Available at: http://www.wiche.edu/pub/12271

(C) Southern Regional Science Association 2015. 